\title{
The Effect of Exogenous 3':5'-Adenosine Monophosphate on Urinary Output in Children with Vasopressin-Resistant Diabetes Insipidus
}

\author{
W. PROESMANS, ${ }^{(19)}$ E. EGGERMONT, M. VANDERSCHUEREN-LODEWEYCKX, H. TIDDENS, AND R. EECKELS
}

Department of Pediatrics, St. Raphael University Hospital, Leuven, Belgium, and the Wilhelmina Children's Hospital, Utrecht, The Netherlands

\section{Extract}

$3^{\prime}: 5^{\prime}$-Adenosine monophosphate (c-AMP) and dibutyryl $3^{\prime}: 5^{\prime}$ adenosine monophosphate (DB c-AMP) were given intravenously to six children with nephrogenic diabetes insipidus. Both nucleotides were unable to reduce, in a constant and reproducible manner, urine volume and free water clearance. Paradoxically, DB c-AMP, given as an infusion, caused a clear-cut rise in urine volume (an increase of $138.0-188.5 \%$, mean of $172.8 \%$, as compared with the preceding periods) without influencing creatinine excretion.

\section{Speculation}

In nephrogenic diabetes insipidus, the basic defect responsible for vasopressin resistance presumably is located beyond the intracellular c-AMP formation. DB c-AMP might diminish the net reabsorption of water and solutes in the proximal renal tubule.

c-AMP is the second messenger of many hormones including the antidiuretic hormone (ADH) (15). Therefore, the administration of exogenous c-AMP mimics the action of the hormone, causing antidiuresis in normal and vasopressin-deficient subjects (11).

The present investigation was undertaken to study the effect of intravenously injected c-AMP and of its dibutyryl derivative (DB c-AMP) on diuresis $(\mathrm{V})$, urine osmolality $\left(\mathrm{U}_{\text {osm }}\right)$ osmolar clearance $\left(\mathrm{C}_{\mathrm{osm}}\right)$, and free water clearance $\left(\mathrm{C}_{\mathrm{H}_{2} \mathrm{O}}\right)$ in six patients with nephrogenic diabetes insipidus (NDI).

\section{METHODS, PATIENTS, AND SPECIAL STUDIES}

\section{METHODS}

All children were studied after informed consent of the parents had been obtained. An intravenous infusion with $5 \%$ glucose or $0.9 \%$ sodium chloride solution was maintained throughout each test at a rate of $0.5-2 \mathrm{ml} / \mathrm{min}$. The volume of infusate expressed in milliliters per minute per square meter varied between 1.35 and 1.88 in the individual patients with a mean of 1.58 . Urine was obtained in 15 -min portions by an indwelling catheter. Plasma samples for measurement of osmolality $\left(\mathrm{P}_{\text {osm }}\right)$ were taken every hour. The patients were not fasted and during the test they were offered water hourly in amounts equal to the urinary output in the preceding clearance period. They regularly took less than these amounts and on the whole, the individual water balances remained unchanged up to the start of the last clearance period. The $U_{o s m}$ was measured as well as its volume which was expressed in milliliters per minute (V). $\mathrm{C}_{\mathrm{osm}}$ and $\mathrm{C}_{\mathrm{H}_{2} \mathrm{O}}$ were calculated according to the equations: $\mathrm{C}_{\text {osm }}=\left(\mathrm{U}_{\text {osm }} \times \mathrm{V}\right) / \mathrm{P}_{\text {osm }}$ and $\mathrm{C}_{\mathrm{H}_{2} \mathrm{O}}=\mathrm{V}-\mathrm{C}_{\mathrm{osm}}$. A Knauer osmometer was used to determine $\mathrm{P}_{\text {osm }}$ and $\mathrm{U}_{\text {osm }}$. Blood glucose was measured by the glucose oxidase method, plasma nonesterified free fatty acids (NEFA) by a modification of the method of Dole (6), and plasma growth hormone $(\mathrm{GH})$ by radioimmunoassay with the use of the double antibody method (16).

$3^{\prime}: 5^{\prime}$-Adenosine monophosphate and $N^{6}-2^{\prime}$-O $O$-dibutyryl adenosine $3^{\prime}: 5^{\prime}$-monophosphate monosodium salts were purchased from Sigma and prepared for human use as follows: the dry powder was dissolved in a $0.9 \%$ solution of $\mathrm{NaCl}$ to a concentration of $5 \mathrm{mg} / \mathrm{ml}$ and adjusted to $\mathrm{pH} 7.4$ with $0.01 \mathrm{~N}$ of $\mathrm{NaOH}$. The solutions were sterilized by filtration on Millipore filters. $\mathrm{L}_{8}$-vasopressin was purchased from Sandoz and diluted in $0.9 \% \mathrm{NaCl}$ solution. The antidiuretic activity of the c-AMP preparation was established by a single injection in one 10-month-old control patient, a mentally retarded, physically healthy infant without any abnormality in renal function. The biologic activity of both the c-AMP and DB c-AMP preparation was shown by their effects on blood glucose, plasma growth hormone, and NEFA in one patient.

\section{PATIENTS}

The six patients have nephrogenic diabetes insipidus (Table 1). The first two are unrelated girls. The third patient, a boy, is the child of a consanguinous marriage between cousins. The three other cases are brothers. All six children showed no other abnormality than their concentration inability which was uninfluenced by vasopressin. Their glomerular filtration, estimated by endogenous creatinine clearance, was normal.

\section{SPECIAL STUDIES}

$A C$, as the first patient with NDI to be submitted to our c-AMP and DB C-AMP investigations, was studied in more detail.

Protocol $I$. Alternating intravenous injections of c-AMP and pitressin at hourly intervals.

In patient $A C$, after a control period of $1 \mathrm{hr}, 6 \mathrm{mg} / \mathrm{kg}$ body wt c-AMP was injected slowly. One hour later, 2 units of pitressin were given by i.v. injection. After the same interval of $1 \mathrm{hr}, \mathrm{c}-\mathrm{AMP}$ injection was repeated at a dose of $10 \mathrm{mg} / \mathrm{kg}$, followed by 1 unit pitressin. In the five other patients with NDI, pitressin was injected only once and at a dose of 0.1 unit.

Protocol II. Infusion of $c-A M P$ and $D B C-A M P$. After a control period of $45-60 \mathrm{~min}, 0.5 \mathrm{mg} / \mathrm{kg} / \mathrm{min} \mathrm{c}-\mathrm{AMP}$ was perfused during $45-60 \mathrm{~min}$, followed by an infusion of $0.2 \mathrm{mg} / \mathrm{kg} / \mathrm{min}$ of $\mathrm{DB}$ c-AMP during the same period of time. Both periods were separated by a wash-out time of $30 \mathrm{~min}$. This experiment was done in the six NDI patients. In patient $A C$, blood glucose, NEFA, and $\mathrm{GH}$ were followed at $15-\mathrm{min}$ intervals.

Protocol III. Injection of $D B C$-AMP, Aminophyllin, and Association of $c-A M P$ and Aminophyllin. After a 30-min control 
period, $5 \mathrm{mg} / \mathrm{kg}$ DB c-AMP and $3 \mathrm{mg} / \mathrm{kg}$ aminophyllin were injected consecutively at $1-\mathrm{hr}$ intervals. After the same interval, both c-AMP, $15 \mathrm{mg} / \mathrm{kg}$, and aminophyllin, $3 \mathrm{mg} / \mathrm{kg}$, were injected simultaneously. This protocol was applied only to patient $A C$.

\section{RESULTS}

\section{PROTOCOL I}

The results of protocol $I$ are shown in Figure 1 and in Table 2. There is no indication of any clear-cut antidiuretic effect either by the two doses of c-AMP, or by pitressin. On the contrary, c-AMP at a dose of $10 \mathrm{mg} / \mathrm{kg}$ is associated with a rise in urinary volume in four patients out of the six. Throughout the successive test periods, there are only minor variations in creatinine excretion.

\section{PROTOCOL II}

The results obtained by applying protocol II are shown in Figure 2 and in Table 3.

The biological activity of the infused cyclic nucleotides is shown in patient $A C$ (Fig. 2) by the changes in serum NEFA, plasma GH, and blood glucose known to occur during the administration of c-AMP and DB c-AMP $(12,13)$. An antidiuresis is only observed in patient $M F$ and to a lesser degree in patient $A C$ under the influence of c-AMP, but is not reproduced during DB c-AMP infusion. In the other patients, the effect of c-AMP on urinary volume is negligible. The infusion with DB c-AMP, on the other

Table 1. Clinical data for children with nephrogenic diabetes insipidus $^{1}$

\begin{tabular}{|c|c|c|c|c|c|c|}
\hline \multirow[b]{2}{*}{$\begin{array}{l}\mathrm{Pa}- \\
\text { tients }\end{array}$} & \multirow[b]{2}{*}{ Sex } & \multicolumn{2}{|c|}{ Age } & \multirow{2}{*}{$\begin{array}{c}\text { Urine } \\
\text { sediment } \\
\text { and } \\
\text { culture }\end{array}$} & \multirow{2}{*}{$\begin{array}{l}\text { Protein- } \\
\text { uria, gluco- } \\
\text { suria }\end{array}$} & \multirow[b]{2}{*}{ I.V.P } \\
\hline & & $\begin{array}{l}\text { Diag- } \\
\text { nosis }\end{array}$ & Study & & & \\
\hline$A C$ & $\mathrm{~F}$ & $5 \mathrm{mo}$ & $6 \mathrm{mo}$ & $\mathrm{Neg}$ & Neg & $\mathrm{nl}$ \\
\hline$N S$ & $\mathrm{~F}$ & $3 \mathrm{mo}$ & $6 \mathrm{mo}$ & $\mathrm{Neg}$ & $\mathrm{Neg}$ & $\mathrm{n} 1$ \\
\hline$M F$ & M & $6 \mathrm{mo}$ & $8 \mathrm{mo}$ & $\mathrm{Neg}$ & Neg & $\mathrm{nl}$ \\
\hline$C E$ & $\mathrm{M}$ & $6 \mathrm{wks}$ & $3 \mathrm{yr}$ & Neg & Neg & $\mathrm{nl}$ \\
\hline$L E$ & $\mathbf{M}$ & $18 \mathrm{mo}$ & $8 \mathrm{yr}$ & $\mathrm{Neg}$ & Neg & $\mathrm{nl}$ \\
\hline$F E$ & $\mathbf{M}$ & 3 yrs & $9 \mathrm{yr}$ & $\mathrm{Neg}$ & $\mathrm{Neg}$ & $\mathrm{nl}$ \\
\hline
\end{tabular}

${ }^{1}$ Neg: negative: I.V.P.: intravenous pyelography; nl: normal.

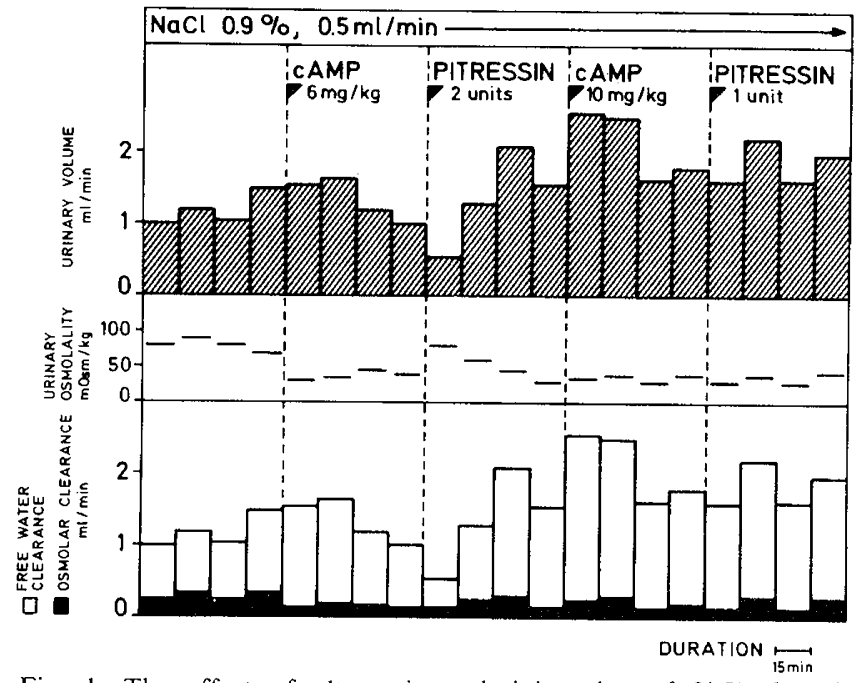

Fig. 1. The effect of alternating administration of $3^{\prime}: 5^{\prime}$-adenosine monophosphate (cAMP) and pitressin in two different dosages each on urinary volume, urinary osmolality, osmolar clearance, and free water clearance in patient $A C$ with nephrogenic diabetes insipidus (protocol $I$ ).
Table 2. Results of alternating injection of $3^{\prime}: 5^{\prime}$-adenosine monophosphate (c-AMP) and pitressin in six patients with nephrogenic diabetes insipidus ${ }^{1}$

\begin{tabular}{|c|c|c|c|c|}
\hline & $\begin{array}{c}\text { Control } \\
\text { period }\end{array}$ & $\begin{array}{l}\mathrm{c}-\mathrm{AMP} \\
6 \mathrm{mg} / \mathrm{kg}\end{array}$ & Pitressin & $\begin{array}{c}\text { c-AMP, } \\
10 \mathrm{mg} / \mathrm{kg}\end{array}$ \\
\hline \multicolumn{5}{|l|}{$A C$} \\
\hline $\mathrm{V}$ & 1.18 & 1.36 & 1.37 & 2.12 \\
\hline$U_{o s m}$ & 79 & 36 & 53 & 34 \\
\hline $\mathrm{C}_{\mathrm{osm}}$ & 0.30 & 0.15 & 0.21 & 0.23 \\
\hline $\mathrm{C}_{\mathrm{H}_{2} \mathrm{O}}$ & 0.88 & 1.21 & 1.16 & 1.89 \\
\hline Creatinine & 0.30 & 0.25 & 0.22 & 0.30 \\
\hline \multicolumn{5}{|l|}{$N S$} \\
\hline V & 1.10 & 0.84 & 0.94 & 1.20 \\
\hline $\mathrm{U}_{\mathrm{osm}}$ & 180 & 134 & 172 & 120 \\
\hline $\mathrm{C}_{\mathrm{osm}}$ & 0.61 & 0.36 & 0.46 & 0.44 \\
\hline $\mathrm{C}_{\mathrm{H}_{2} \mathrm{O}}$ & 0.49 & 0.48 & 0.48 & 0.76 \\
\hline Creatinine & 0.28 & 0.19 & 0.26 & 0.21 \\
\hline \multicolumn{5}{|l|}{$M F$} \\
\hline V & 1.58 & 1.66 & 1.43 & 2.03 \\
\hline$U_{\mathrm{osm}}$ & 98 & 61 & 86 & 52 \\
\hline $\mathrm{C}_{\text {osm }}$ & 0.44 & 0.40 & 0.43 & 0.36 \\
\hline $\mathrm{C}_{\mathrm{H}_{2} \mathrm{O}}$ & 1.14 & 1.26 & 1.00 & 1.67 \\
\hline Creatinine & 0.32 & 0.29 & 0.29 & 0.31 \\
\hline \multicolumn{5}{|l|}{$C E$} \\
\hline V & 2.45 & 2.43 & 3.50 & 3.79 \\
\hline$U_{\mathrm{osm}}$ & 71 & 63 & 48 & 42 \\
\hline $\mathrm{C}_{\mathrm{osm}}$ & 0.56 & 0.50 & 0.56 & 0.52 \\
\hline $\mathrm{C}_{\mathrm{H}_{2} \mathrm{O}}$ & 1.89 & 1.93 & 2.94 & 3.27 \\
\hline Creatinine & 0.53 & 0.53 & 0.61 & 0.58 \\
\hline \multicolumn{5}{|l|}{$L E$} \\
\hline $\mathrm{V}$ & 7.65 & 6.87 & 7.31 & 5.23 \\
\hline$U_{o s m}$ & 78 & 59 & 50 & 54 \\
\hline $\mathrm{C}_{\mathrm{osm}}$ & 2.20 & 1.41 & 1.36 & 1.08 \\
\hline $\mathrm{C}_{\mathrm{H}_{2} \mathrm{O}}$ & 5.45 & 5.46 & 5.95 & 4.15 \\
\hline Creatinine & 0.91 & 0.73 & 0.73 & 0.70 \\
\hline \multicolumn{5}{|l|}{$F E$} \\
\hline V & 7.36 & 6.42 & 6.89 & 13.83 \\
\hline $\mathrm{U}_{\mathrm{osm}}$ & 67 & 65 & 59 & 70 \\
\hline $\mathrm{C}_{\mathrm{osm}}$ & 1.71 & 1.38 & 1.41 & 3.69 \\
\hline $\mathrm{C}_{\mathrm{H}_{2} \mathrm{O}}$ & 5.65 & 5.04 & 5.48 & 10.14 \\
\hline Creatinine & 0.85 & 0.75 & 0.93 & 0.98 \\
\hline
\end{tabular}

${ }^{1}$ The figures are mean values of urine volume $(\mathrm{V})$ and osmolality $\left(\mathrm{U}_{\mathrm{osm}}\right)$, osmolar clearance $\left(\mathrm{C}_{\mathrm{osm}}\right)$, free water clearance $\left(\mathrm{C}_{\mathrm{H}_{2} \mathrm{O}}\right)$, and creatinine excretion for each period. $\mathrm{V}, \mathrm{C}_{\mathrm{osm}}$, and $\mathrm{C}_{\mathrm{H}_{2} \mathrm{O}}$ are expressed as milliliters per minute, $\mathrm{U}_{\mathrm{osm}}$ as milliosmolar concentration per kilogram $\mathrm{H}_{2} \mathrm{O}$ and creatinine excretion as milligrams per minute and per $1.73 \mathrm{~m}^{2}$.

hand, results in a rise of urinary volume in all patients. As during protocol $I$, the creatinine excretions remain unchanged.

\section{PROTOCOL III}

The results are presented in Table 4 .

There was no antidiuresis during the whole procedure. On the contrary, urinary volumes rose steadily together with $\mathrm{C}_{\mathrm{osm}}$ and $\mathrm{C}_{\mathrm{H}, \mathrm{O}}$. Creatinine excretion remained unchanged.

\section{DISCUSSION}

c-AMP is the intracellular mediator of the ADH or vasopressin. The role of C-AMP as the second messenger of $\mathrm{ADH}$ has been demonstrated by the following experiments: $(I)$ c-AMP changes the permeability to water in the isolated toad bladder in the same way as does vasopressin (14); (2) vasopressin increases the intracellular concentration of c-AMP in the toad bladder $(3,9) ;(3)$ vasopressin activates adenylcyclase in the rat renal medulla (4); (4) exogenous c-AMP, given to normal and vasopressin-deficient 


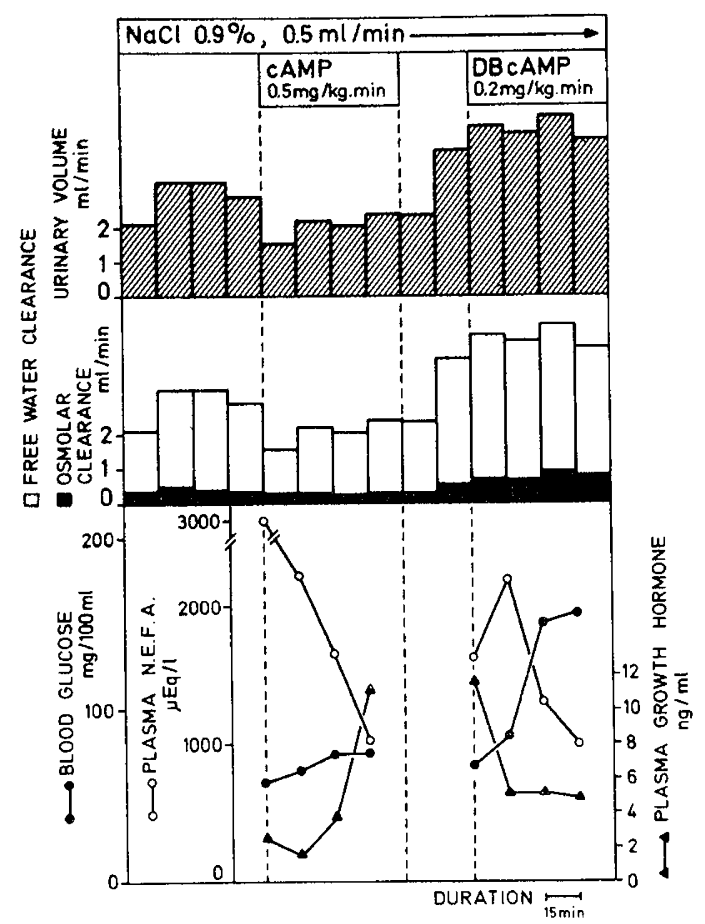

Fig. 2. Values of urinary volume, osmolar clearance, and free water clearance, blood glucose, plasma nonesterified fatty acids and growth hormone levels in patient $A C$ before and during $3^{\prime}: 5^{\prime}$-adenosine monophosphate $(c A M P)$ or dibutyryl $3^{\prime}: 5^{\prime}$-adenosine monophosphate $(D B C-A M P)$ (protocol II).

subjects, reduces $\mathrm{V}$ and $\mathrm{C}_{\mathrm{H}_{2} \mathrm{O}}$ in a clear-cut fashion (11). This finding was confirmed in our control patients as shown in Figure 3. The exact mechanism by which c-AMP changes the permeability of the tubular membrane is unknown. It has been assumed (7) that c-AMP activates a specific protein kinase. This in turn catalyzes the phosphorylation of a membrane protein, bringing about a change in the structure of the membrane and enhancing its permeability to water. Accordingly, the effectuation of normal vasopressin activity would involve a chain of biochemical processes. It seems useful to subdivide the overall mechanism into two major steps: (I) hormone-stimulated formation of c-AMP and (2) c-AMP-initiated increase of membrane permeability to water. NDI is a so-called pseudo-endocrine disorder, i.e., a disease in which there is no hormone deficit but an end-organ unresponsiveness to the hormone, in this case ADH. Theoretically, NDI could result from a defect in either of both steps of vasopressin action. A defect in the first step could result either from an anomaly of the cellular membrane receptor or from the inactivity of adenylcyclase. In both cases, one would expect exogenous c-AMP to promote antidiuresis in this disease. Our studies are clearly not in favor of this first hypothesis.

In our six patients with NDI no reproducible reduction of $\mathrm{V}$ and $\mathrm{C}_{\mathrm{H}, \mathrm{O}}$ was obtained either after pitressin or C-AMP and DB c-AMP administration. Our findings confirm those of Avery et al. (1). These authors reported briefly on the effect of c-AMP and DB c-AMP by constant infusion to patients with NDI. They did not observe any change in $\mathrm{C}_{\mathrm{H}_{2} \mathrm{O}}, \mathrm{U}_{\mathrm{osm}}$, and glomerular filtration rate during c-AMP infusion. In contrast, DB c-AMP increased $\mathrm{C}_{\mathrm{H}_{2} \mathrm{O}}$. We found the same seemingly paradoxical effect of DB c-AMP together with a definite rise in the urinary volumes in our six patients. At the dosages used, especially in protocol $I I$, the differences between C-AMP and DB c-AMP are unmistakable. The effect of DB c-AMP cannot be attributed to changes in the glomerular filtration rate, since the creatinine excretion remains unchanged during the several test periods. Neither did overhydration play a role: the patients' water balances were roughly in equilibrium at the beginning of the DB c-AMP infusion. There-
Table 3. Results of $3^{\prime}: 5^{\prime}$-adenosine monophosphate $(c-A M P)$ and dibutyryl $3^{\prime}: 5^{\prime}$-adenosine monophosphate (DBC-AMP) perfusions in six patients with nephrogenic diabetes insipidus ${ }^{1}$

\begin{tabular}{|c|c|c|c|c|}
\hline & $\begin{array}{l}\text { Control } \\
\text { period }\end{array}$ & $\begin{array}{c}\mathrm{c}-\mathrm{AMP} \\
0.5 \mathrm{mg} / \mathrm{kg} \cdot \min \end{array}$ & Wash-out & $\begin{array}{c}\text { DB c-AMP, } \\
0.2 \mathrm{mg} / \mathrm{kg} \cdot \mathrm{min}\end{array}$ \\
\hline \multicolumn{5}{|l|}{$A C$} \\
\hline V & 2.90 & 2.03 & 3.29 & 4.82 \\
\hline $\mathrm{U}_{\mathrm{osm}}$ & 40 & 37 & 36 & 47 \\
\hline $\mathrm{C}_{\text {osm }}$ & 0.38 & 0.25 & 0.41 & 0.78 \\
\hline $\mathrm{C}_{\mathrm{H}_{2} \mathrm{O}}$ & 2.52 & 1.78 & 2.88 & 4.04 \\
\hline Creatinine & 0.35 & 0.32 & 0.34 & 0.34 \\
\hline \multicolumn{5}{|l|}{$N S$} \\
\hline V & 0.89 & 1.08 & 0.86 & 1.69 \\
\hline $\mathrm{U}_{\mathrm{osm}}$ & 147 & 114 & 163 & 105 \\
\hline $\mathrm{C}_{\mathrm{osm}}$ & 0.44 & 0.41 & 0.47 & 0.62 \\
\hline $\mathrm{C}_{\mathrm{H}_{2} \mathrm{O}}$ & 0.45 & 0.67 & 0.39 & 1.07 \\
\hline Creatinine & 0.26 & 0.23 & 0.23 & 0.22 \\
\hline \multicolumn{5}{|l|}{$M F$} \\
\hline $\mathrm{V}$ & 1.53 & 0.68 & 1.65 & 2.23 \\
\hline $\mathrm{U}_{\mathrm{osm}}$ & 61 & 111 & 104 & 54 \\
\hline $\mathrm{C}_{\mathrm{osm}}$ & 0.29 & 0.26 & 0.58 & 0.41 \\
\hline $\mathrm{C}_{\mathrm{H}_{2} \mathrm{O}}$ & 1.24 & 0.42 & 1.07 & 1.82 \\
\hline Creatinine & 0.25 & 0.21 & 0.28 & 0.25 \\
\hline \multicolumn{5}{|l|}{$C E$} \\
\hline V & 3.58 & 3.53 & 3.95 & 5.09 \\
\hline $\mathrm{U}_{\mathrm{osm}}$ & 92 & 53 & 44 & 45 \\
\hline $\mathrm{C}_{\mathrm{osm}}$ & 1.10 & 0.66 & 0.60 & 0.79 \\
\hline $\mathrm{C}_{\mathrm{H}_{2} \mathrm{O}}$ & 2.48 & 2.87 & 3.35 & 4.30 \\
\hline Creatinine & 0.44 & 0.40 & 0.44 & 0.42 \\
\hline \multicolumn{5}{|l|}{$L E$} \\
\hline V & 5.89 & 5.22 & 7.21 & 11.51 \\
\hline$U_{\text {osm }}$ & 136 & 116 & 88 & 83 \\
\hline $\mathrm{C}_{\mathrm{osm}}$ & 2.75 & 2.15 & 2.12 & 3.40 \\
\hline $\mathrm{C}_{\mathrm{H}_{2} \mathrm{O}}$ & 3.14 & 3.07 & 5.09 & 8.11 \\
\hline Creatinine & 0.76 & 0.70 & 0.72 & 0.73 \\
\hline \multicolumn{5}{|l|}{$F E$} \\
\hline $\mathrm{V}$ & 8.43 & 7.58 & 6.63 & 13.76 \\
\hline $\mathrm{U}_{\mathrm{osm}}$ & 78 & 80 & 75 & 87 \\
\hline $\mathrm{C}_{\mathrm{H}_{2} \mathrm{O}}$ & 2.45 & 2.19 & 1.62 & 4.22 \\
\hline $\mathrm{C}_{\mathrm{H}_{2} \mathrm{O}}$ & 5.98 & 5.39 & 5.01 & 9.54 \\
\hline Creatinine & 0.76 & 0.81 & 0.77 & $0.79^{\circ}$ \\
\hline
\end{tabular}

${ }^{1}$ For explanation of data, see footnote 1 of Table 2.

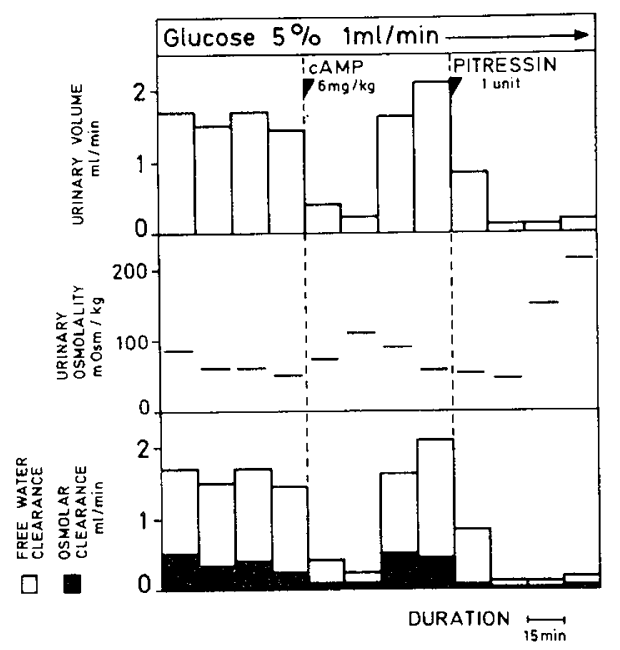

Fig. 3. The effect of $3^{\prime}: 5^{\prime}$-adenosine monophosphate $(c-A M P)$ and pitressin on urinary volume, urinary osmolality, osmolar clearance, and free water clearance in a normal control child. 
Table 4. Results of alternating injection of dibutyryl $3^{\prime}: 5^{\prime}$-adenosine monophosphate $(D B C-A M P)$, aminophyllin, and $3^{\prime}: 5^{\prime}$-adenosine monophosphate $(c-A M P)$ combined with aminophyllin in patient $A C$ with nephrogenic diabetes insipidus ${ }^{1}$

\begin{tabular}{lcccc}
\hline & $\begin{array}{c}\text { Control } \\
\text { period }\end{array}$ & $\begin{array}{c}\text { DB c-AMP, } \\
5 \mathrm{mg} / \mathrm{kg}\end{array}$ & $\begin{array}{c}\text { Amino- } \\
\text { phyllin, } \\
3 \mathrm{mg} / \mathrm{kg}\end{array}$ & $\begin{array}{c}\text { c-AMP, } \\
15 \mathrm{mg} / \mathrm{kg}, \\
\text { Amino- } \\
\text { phyllin }\end{array}$ \\
\hline $\mathrm{V}$ & 2.52 & 2.91 & 4.16 & 5.23 \\
$\mathrm{U}_{\text {osm }}$ & 34 & 32 & 35 & 32 \\
$\mathrm{C}_{\text {osm }}$ & 0.28 & 0.30 & 0.48 & 0.72 \\
$\mathrm{C}_{\mathrm{H}_{2} \mathrm{O}}$ & 2.24 & 2.60 & 3.68 & 4.51 \\
Creatinine & 0.36 & 0.35 & 0.34 & 0.35 \\
\hline
\end{tabular}

${ }^{1}$ For explanation of data, see footnote 1 of Table 2.

fore, one might postulate that at least in patients with NDI, DB c-AMP diminishes the water reabsorption at the level of the proximal renal tubule. Such an effect would indeed account for the observed changes in $\mathrm{V}, \mathrm{C}_{\mathrm{H}_{2} \mathrm{O}}$, and $\mathrm{C}_{\mathrm{osm}}$. It is noteworthy that a diuretic effect combined with stable creatinine excretion was also the salient feature observed in protocol $I I I$. This indicates that in NDI patients aminophyllin does not restore the antidiuretic effect of c-AMP observed in normal individuals.

Jones et al. (10) found that c-AMP transiently reduced urinary output in two of three patients with NDI. A similar effect was noted but only irregularly in two of our six patients. It was, however, rather mild, so that the changes observed could have been spontaneous ones. Avery's and our results would indicate that the pathogenesis of NDI is located beyond c-AMP formation and consists of a defect in the second step of vasopressin action. However, experiments of Fichman and Brooker (8) are at variance with this "second step hypothesis." These authors observed a deficient urinary c-AMP excretion after infusion of pitressin in NDI patients. They concluded therefore that the pathogenesis of NDI is analogous to that of pseudohypoparathyroidism (PHP). PHP is indeed an example of a pseudoendocrine disorder in which a first step defect is likely to be present. In patients with PHP, Chase et al. (5) showed a defective excretion of c-AMP in response to parathyroid hormone administration, whereas Bell et al. (2) found that DB c-AMP can reproduce the effect of parathyroid hormone. In contrast to the apparently clear-cut situation in PHP, the deficient renal c-AMP excretion under influence of exogenous $\mathrm{ADH}$ on one hand and the inactivity of c-AMP infusions on the other hand is paradoxical in NDI. Concerning these apparently contradictory facts, three remarks require consideration. First, the lack of urinary increase of c-AMP after pitressin administration could be the result of a defective release from the collecting duct cells. This possibility, among others, is put forward by Fichman and Brooker (8). It would be in keeping with the knowledge that, whatever its pathogenesis, NDI is characterized by a disturbance in the permeability of the cell membrane on the tubular lumenal side, the membrane through which intracellular c-AMP is thought to leak into the urine. The second point is that exogenous c-AMP could be unable to enter the target cells and mimic the effect of the hormone. In that respect, it may be pointed out that, in our studies, c-AMP and DB c-AMP were used in relatively high doses and given both as a single shot and in perfusion. Last, it cannot be excluded that in NDI the intracellular breakdown of c-AMP in the renal tubular cells is so high that the cyclic nucleotide cannot exert its normal activity. This could also explain the low values of urinary c-AMP excretion found to occur in NDI patients after parathyroid hormone administration (8).

\section{SUMMARY}

The administration of c-AMP and DB c-AMP to six children with NDI has failed to yield an antidiuretic effect. From the present study it may be concluded that, at the doses used, neither c-AMP nor its dibutyryl derivative can mimic the action of ADH in NDI as they do in normal subjects. On the contrary, DB c-AMP increases urine volume and $\mathrm{C}_{\text {osm }}$ in a very marked way, without changing the creatinine excretion.

\section{REFERENCES AND NOTES}

1. Avery, S., Clark, M., Trygstad, C., and Bell, N. H.: Effects of cyclic adenosine monophosphate and dibutyryl cyclic AMP in antidiuretic hormone-deficient and antidiuretic hormone-resistant diabetes insipidus. J. Clin. Invest., 50: 3a (1971).

2. Bell, N. H., Avery, S., Sinha, T., Clark, C. M., Allen, D. O., and Johnston, C.: Effects of dibutyryl cyclic adenosine $3^{\prime}, 5^{\prime}$-monophosphate and parathyroid extract on calcium and phosphorus metabolism in hypoparathyroidism and pseudohypoparathyroidism. J. Clin. Invest., 51: 816 (1972).

3. Brown, E., Clarki, D. I.., Roux, V., and Sherman, G. H.: The stimulation of adenosine $3^{\prime}, 5^{\prime}$-monophosphate production by antidiuretic factors. J. Biol. Chem., 238: 852 (1963).

4. Chase, L. R., and Aurbach, G. D.: Renal adenyl cyclase: Anatomically separate sites for parathyroid hormone and vasopressin. Science, 159: 545 (1968)

5. Chase, L. R., Melson, G. L., and Aurbach, G. D.: Pseudohypoparathyroidism: Defective excretion of $3^{\prime}, 5^{\prime}$-AMP in response to parathyroid hormone. $J$, Clin. Invest., 48: 1832 (1969).

6. Dole, V. P.: A relation between non esterified fatty acids in plasma and the metabolism of glucose. J. Clin. Invest., 35: 150 (1956).

7. Dousa, T. P., Walter, R., Schwartz, I. L., Sands, H., and Hechter, O.: Role of cyclic AMP in the action of neurohypophyseal hormones on kidney. Advan. Cyclic Nucl., I: 121 (1972).

8. Fichman, M. P., and Brooker, G.: Deficient renal cyclic adenosine 3',5'-monophosphate production in nephrogenic diabetes insipidus. J. Clin. Endocrinol. Metabol., 35: 35 (1972).

9. Handler, J. S., Butcher, R. L., Sutherland, E. W., and Orloff, J.: The effect of vasopressin and of theophylline on the concentration of adenosine $33^{\prime}, 5^{\prime}$-phosphate in the urinary bladder of the toad. J. Biol. Chem., 240: 4524 (1965).

10. Jones, N. F., Barradough, M. A., Barnes, N., and Cottom, D. G.: Nephrogenic diabetes insipidus: Effects of 3, 5, cyclic-adenosine monophosphate. Arch. Dis. Childhood, 47: 794 (1972).

11. Levine, R. A.: Antidiuretic responses to exogenous adenosine $3^{\prime}, 5^{\prime}$-monophosphate in man. Clin. Sci., 34: 253 (1968).

12. Levine, R. A.: Effects of exogenous adenosine $3^{\prime}, 5^{\prime}$-monophosphate in man: Glucose, non esterified fatty acids, and cortisol responses. Metabol. Clin. Exp., 17: 34 (1968).

13. Levine, R. A.: Stimulation of plasma insulin and growth hormone in man by adenosine $3^{\prime}, 5^{\prime}$-monophosphate. J. Clin. Invest., 47: 62a (1968).

14. Orloff, J., and Handler, J. S.: The similarity of effects of vasopressin, adenosine $3^{\prime}$,-monophosphate and theophylline on the toad bladder. J. Clin. Invest., 41 : $702(1962)$.

15. Robison, G. A., Butcher, R. W., and Sutherland, E. W.: Cyclic AMP (Academic Press, New York, 1971).

16. Schalch, D. S., and Parker, M. L.: A sensitive double antibody immuno-assay for human growth hormone in plasma. Nature, 203: 1141 (1964).

17. Presented as a paper at the Sixth Annual Meeting of the European Society for Pediatric Nephrology, Dublin, 1972.

18. Dr. M. Vandirschueren-Lodeweyckx was Aangesteld Navorser of the Belgian Nationaal Fonds Voor Wetenschappelijk Onderzoek.

19. Requests for reprints should be addressed to: W. Proesmans, M.D., A. Z. St. Raphael, Department of Pediatrics, University of Leuven, Belgium.

20. Accepted for publication January 12, 1974. 